\title{
Characterization of candidate gene copy number alterations in the 11 q13 region along with BRAF and NRAS mutations in human melanoma
}

\author{
Viktória Lázár ${ }^{1}$, Szillvia Ecsedi ${ }^{1}$, Attila G,Szöllősi ${ }^{2}$, Réka Tóth ${ }^{1}$, Laura Vízkeleti ${ }^{1}$, \\ Zsuzsa Rákosy ${ }^{1,3}$, Ágnes Bégány ${ }^{4}$, Róza Ádány ${ }^{1,3}$ and Margit Balázs ${ }^{1,3}$ \\ ${ }^{1}$ Department of Preventive Medicine, Faculty of Public Health, Medical and Health Science Center, University \\ of Debrecen, Debrecen, Hungary; ${ }^{2}$ Department of Physiology, Faculty of Medicine, Medical and Health \\ Science Center, University of Debrecen, Debrecen, Hungary; ${ }^{3}$ Public Health Research Group of the Hungarian \\ Academy of Sciences, University of Debrecen, Debrecen, Hungary and ${ }^{4}$ Department of Dermatology, Faculty \\ of Medicine, Medical and Health Science Center University of Debrecen, Debrecen, Hungary
}

\begin{abstract}
Amplification of the 11q13 chromosomal region is a common event in primary melanomas. Several candidate genes are localized at this sequence; however, their role in melanoma has not been clearly defined. The aim of this study was to develop an accurate method for determining the amplification pattern of six candidate genes that map to this amplicon core and to elucidate the possible relationship between BRAF, NRAS mutations and CCND1 copy number alterations, all of which are key components of the MAP kinase pathway. Characterization of gene copy numbers was performed by quantitative PCR and, as an alternative method, fluorescence in situ hybridization was used to define the CCND1 amplification pattern at the single cell level. Samples with amplified CCND1 (32\%) were further analyzed for copy number alterations for the TAOS1, FGF3, FGF19, FGF4 and EMS1 genes. Coamplification of the CCND1 and TAOS1 was present in $15 \%$ of tumors and was more frequent in ulcerated lesions $(P=0.017)$. Furthermore, $56 \%$ of primary melanomas had either $B R A F$ or NRAS mutations, but these two mutations were not present in any of the lesions analyzed. Of these cases, $34 \%$ also had CCND1 amplification. There was a significant relationship between NRAS activating mutations and UV exposure $(P=0.005)$. We did not find correlations between CCND1 gene amplification status and any of the patients' clinicopathological parameters. However, CCND1 amplification simultaneously with either BRAF or NRAS activation mutations was observed mainly in primary tumors with ulcerated surfaces $(P=0.028)$. We assume that coamplification of these candidate genes in the 11 q13 region or CCND1 gene alterations along with either BRAF or NRAS mutations might be more important for prognosis than the presence of these alterations alone. Modern Pathology (2009) 22, 1367-1378; doi:10.1038/modpathol.2009.109; published online 24 July 2009
\end{abstract}

Keywords: melanoma; 11q13 amplicon core; CCND1 gene amplification; TAOS1; BRAF; NRAS

Malignant melanoma is the most aggressive form of skin cancer and has a multifactorial etiology. It is assumed that the disease progresses toward aggres-

Correspondence: Dr M Balázs, PhD, DSc, Division of Biomarker Analysis, Department of Preventive Medicine, Faculty of Public Health, Medical and Health Science Center, University of Debrecen, Kassai str. 26, Debrecen H-4028, Hungary.

E-mail: margo@dote.hu

Received 21 April 2009; revised 25 June 2009; accepted 26 June 2009; published online 24 July 2009 sive metastatic disease via the accumulation of nonrandom multiple genetic aberrations. ${ }^{1}$

Earlier, using comparative genomic hybridization (CGH) analysis, we and others found frequent amplification of the 11q13-q21 chromosome band in primary melanomas. ${ }^{2-4}$ The Cyclin D1 (CCND1) gene has been widely considered to be a target gene in the region because its overexpression is commonly observed in several human cancers, including breast, head and neck, and bladder cancers. ${ }^{5-7}$ Beside the CCND1, several other oncogenes and/or 
cancer-related genes reside within this amplicon core, such as TAOS1, FGF3, FGF4, FGF19 and EMS1. ${ }^{8-13}$

CCND1 is the regulator subunit of cyclindependent kinase $4(C D K 4)$ and cyclin-dependent kinase $6(C D K 6)$. These enzymes are responsible for phosphorylating the retinoblastoma $(\mathrm{Rb})$ protein and thus promoting cell entry into mitosis. Transcription of CCND1 is stimulated by the MAP kinase pathway, and this is the connection point between the RAS-MAPK and p16-CCND1/ CDK4-Rb pathways. ${ }^{14,15}$ Elevated CCND1 gene copies were found in a large series of acral melanoma subtypes, occasional amplification was described in lentigo maligna melanomas and superficial spreading melanomas (SSM), and only sporadic amplification in the nodular melanoma subtype (NM). ${ }^{16,17}$

The contribution of other genes in the $11 \mathrm{q} 13$ amplicon to several cancers has been investigated. ${ }^{8-13}$ The TAOS1 gene, which is located approximately $12 \mathrm{~kb}$ distal to $C C N D 1$, was found to be a novel marker for advanced esophageal squamous cell carcinoma and was overexpressed only if its gene amplification was present in the oral squamous cell carcinoma cell lines. ${ }^{9,13}$ Amplification of the EMS1 gene through the overexpression of cortactin protein has been shown to contribute to the invasive potential of tumor cells. ${ }^{11,18}$ This protein is described as an actin-associated scaffolding protein that regulates the formation of actin-based structures closely associated with cell motility. ${ }^{19}$ Overexpression of EMS1 causes enhanced cell proliferation, predicts early recurrence and reduced survival in squamous cell carcinoma of the head and neck and in esophageal adenocarcinoma. , $^{8,221}$ CCND1 and EMS1 are also thought to be likely to play pathogenic roles in the 11q13 amplicon in bladder tumors. $^{22}$ Coamplification of CCND1, EMS1, FGF3 and FGF4 genes was significantly associated with increased tumor stage and grade in a large series of urinary bladder cancer. ${ }^{12}$ However, the possible role of these candidate genes within the $11 \mathrm{q} 13$ amplicon has not yet been investigated in primary melanoma.

Activating mutations in codon 600 of $B R A F$ and in codon 61 of NRAS are, so far, the most common single mutations detected in human cutaneous melanoma. ${ }^{23,24}$ Drugs targeting this pathway are, therefore, the most attractive clinical agents for the disease. ${ }^{25}$ A subset of BRAF mutant melanomas are sensitive to these agents, examples of which are SB590885 (GlaxoSmithKline, Collegeville, PA, USA) and PLX-4032/PLX-4720 (Plexxikon, Berkley, CA, USA). ${ }^{26-28}$ Identifying concomitant genetic alterations may help predict the response or resistance to $B R A F$ and NRAS inhibitors.

One of the objectives of our study was to investigate gene copy number alterations in the 11q13 amplicon in primary and metastatic melanomas by performing Q-PCR analysis. First we focused on the detection of CCND1 copy number alterations. All samples with amplified CCND1 were further examined for copy number alteration of TAOS1, FGF3, FGF4, FGF19 and EMS1. Although it is well documented that there is a high prevalence of $B R A F$ (V600) and NRAS (Q61) mutations in melanoma, there are a few studies with discordant findings. These studies examined CCND1 copy number alterations in conjunction with $B R A F$ and NRAS mutational status of the disease. Another aim of our study was to elucidate the possible relationship between these oncogenes and their combined incidence and clinicopathological parameters. Furthermore, we compared CCND1 copy number alterations as classified by real-time quantitative PCR (Q-PCR) with those classified by interphase fluorescence in situ hybridization (FISH) at a single cell level.

\section{Materials and methods}

\section{Tumor Samples and DNA Isolation}

Tumors were collected in the Department of Dermatology, Medical and Health Science Center, University of Debrecen, Hungary. The study was approved by the Regional and Institutional Ethics Committee, Medical and Health Science Center, University of Debrecen, and conducted according to regulations. Written informed consent was always obtained from the patients. Tumor diagnosis was carried out on formalin-fixed paraffin-embedded tissue sections using hematoxylin and eosin staining. Melanoma tumor staging was determined according to the new TNM staging system. ${ }^{29}$ The distinction between tumor groups arising from chronically sun-exposed site or intermittently sunexposed site was based on the presence or absence of solar elastosis of the dermis surrounding the melanomas.

Clinicopathological data from the 68 primary tumors are summarized in Table 1. DNA from peripheral blood cells of healthy individuals and DNA from a melanoma cell line (M24) were also included into the analysis. Tumor DNA was extracted using the G-spin Genomic DNA Extraction Kit following the instructions of the manufacturer (Macherey-Nagel, Düren, Germany). NucleoSpin Extract II kit (Macherey-Nagel) was used to purify DNA if needed. Only high quality DNA template was accepted, with an absorbance ratio range of $1.8-1.9(260-280 \mathrm{~nm})$ or $1.7-2.5$ (260$230 \mathrm{~nm}$ ), as measured by the NanoDrop 1000 instrument (NanoDrop Technologies, Wilmington, De, USA). Control DNA was extracted from peripheral blood cells using the Nucleo Spin Blood mini kit according to the manufacturer's instructions (Macherey-Nagel). All DNA samples were stored at $-20^{\circ} \mathrm{C}$. 
Table 1 Associations of CCND1 amplification, CCND1/TAOS1 coamplification, BRAF and NRAS mutation with clinicopathological parameters of patients

\begin{tabular}{|c|c|c|c|c|c|c|c|c|}
\hline & $\begin{array}{c}C C N D 1^{\mathrm{a}} \\
\mathrm{n} / \operatorname{total}(\%)\end{array}$ & $\mathrm{P}$ & $\begin{array}{c}\text { CCND1/TAOS1 } 1^{\mathrm{b}} \\
\mathrm{n} / \text { total }(\%)\end{array}$ & $\mathrm{P}$ & $\begin{array}{c}B R A F+^{\mathrm{c}} \\
\mathrm{n} / \operatorname{total}(\%)\end{array}$ & $\mathrm{P}$ & $\begin{array}{c}N R A S+\mathrm{d} \\
\mathrm{n} / \operatorname{total}(\%)\end{array}$ & $\mathrm{P}$ \\
\hline All tumor & $22 / 68(32)$ & - & 10/68 (15) & - & 25/68 (37) & - & 13/68 (19) & - \\
\hline \multicolumn{9}{|l|}{ Tumor type } \\
\hline NM & 10/26 (39) & \multirow{2}{*}{0.433} & $4 / 26(15)$ & \multirow{2}{*}{1.000} & $9 / 26(35)$ & \multirow{2}{*}{0.802} & $7 / 26(27)$ & \multirow{2}{*}{0.220} \\
\hline SSM & $12 / 42(29)$ & & $6 / 42(14)$ & & $16 / 42(38)$ & & $6 / 42(14)$ & \\
\hline \multicolumn{9}{|l|}{ Gender } \\
\hline Male & 13/33 (39) & \multirow[t]{2}{*}{0.302} & 5/33 (15) & \multirow[t]{2}{*}{1.000} & 13/33 (39) & \multirow{2}{*}{0.802} & 6/33 (18) & \multirow[t]{2}{*}{1.000} \\
\hline Female & $9 / 35(26)$ & & $5 / 35(14)$ & & $12 / 35(34)$ & & $7 / 35(20)$ & \\
\hline \multicolumn{9}{|l|}{ Age } \\
\hline $20-50$ & 6/18 (33) & \multirow[t]{2}{*}{1.000} & 4/18 (22) & \multirow[t]{2}{*}{0.437} & $5 / 18(28)$ & \multirow[t]{2}{*}{0.407} & $1 / 18(6)$ & \multirow[t]{2}{*}{0.160} \\
\hline$>50$ & $16 / 50(32)$ & & $6 / 50(12)$ & & $20 / 50(40)$ & & $12 / 50(24)$ & \\
\hline \multicolumn{9}{|l|}{ Breslow thickness ${ }^{\mathrm{e}}(\mathrm{mm})$} \\
\hline$<2.00$ & $8 / 27(30)$ & \multirow[t]{3}{*}{$0.430^{\mathrm{f}}$} & $3 / 27(11)$ & \multirow[t]{3}{*}{$0.079^{f}$} & $7 / 27(26)$ & \multirow[t]{3}{*}{$0.801^{\mathrm{f}}$} & $5 / 27(19)$ & \multirow[t]{3}{*}{$1.000^{\mathrm{f}}$} \\
\hline $2.01-4.00$ & $3 / 13(23)$ & & $0 / 13(0)$ & & $7 / 13(54)$ & & $3 / 13(23)$ & \\
\hline$>4.00$ & $11 / 28(39)$ & & $7 / 28(25)$ & & $11 / 28(39)$ & & $5 / 28(18)$ & \\
\hline \multicolumn{9}{|l|}{ Clark's level } \\
\hline I, II, III & $8 / 31(26)$ & \multirow[t]{2}{*}{0.313} & $2 / 31(7)$ & \multirow[t]{2}{*}{0.097} & $11 / 31(36)$ & \multirow[t]{2}{*}{1.000} & 4/31 (13) & \multirow[t]{2}{*}{0.354} \\
\hline IV, V & $14 / 37(38)$ & & $8 / 37(22)$ & & $14 / 37(38)$ & & $9 / 37(24)$ & \\
\hline \multicolumn{9}{|l|}{ Ulceration } \\
\hline Absent & 7/31 (23) & \multirow[t]{2}{*}{0.129} & $1 / 31(3)$ & \multirow[t]{2}{*}{0.017} & 9/31 (29) & \multirow[t]{2}{*}{0.313} & $5 / 31(16)$ & \multirow[t]{2}{*}{0.758} \\
\hline Present & $15 / 37(41)$ & & $9 / 37(24)$ & & $16 / 37(43)$ & & $8 / 37(22)$ & \\
\hline \multicolumn{9}{|l|}{ Anatomic site } \\
\hline Intermittently sun-exposed site & $17 / 53(32)$ & 1.000 & $7 / 53(13)$ & 0.680 & $21 / 53(40)$ & 0.545 & $6 / 53(11)$ & 0.005 \\
\hline Chronically sun-exposed sites & $5 / 15(33)$ & & $3 / 15(20)$ & & $4 / 15(27)$ & & $7 / 15(47)$ & \\
\hline Metastasis formation ${ }^{\mathrm{g}}$ & & & & & & & & \\
\hline Nonmetastatic & $7 / 25(28)$ & 0.406 & $2 / 25(8)$ & 0.273 & $8 / 25(32)$ & 1.000 & $4 / 25(16)$ & 0.350 \\
\hline Metastatic & $13 / 32(41)$ & & $7 / 32(22)$ & & $11 / 32(34)$ & & 9/32 (28) & \\
\hline
\end{tabular}

NM, nodular melanoma; SSM, superficial spreading melanoma.

${ }^{\mathrm{a}}$ Number of tumors with CCND1 amplification.

${ }^{\mathrm{b}}$ Number of tumors with CCND1/TAOS1 coamplification.

${ }^{\mathrm{C}}$ Number of tumors with $B R A F$ codon 600 mutation.

${ }^{\mathrm{d}}$ Number of tumors with NRAS codon 61 mutation.

e Thickness categories based on the current melanoma staging system.

${ }^{\mathrm{f}}<4.00$ versus $>4.00 \mathrm{~mm}$.

${ }^{\mathrm{g}}$ Only patients with at least 3 years of follow-up were included.

\section{FISH Analysis of CCND1}

FISH was performed on tumor imprint preparations using the LSI Cyclin D1 (11q13) SpectrumOrange/ CEP 11 SpectrumGreen Probe (Vysis, Downers Grove, USA) as described previously. ${ }^{30}$ This is a mixture of two probes: the CCND1 probe is approximately $300 \mathrm{~kb}$ long, containing the CCND1 gene, and the second probe is specific for the D11Z1 alpha satellite centromeric repeat of chromosome 11. CCND1 copy number alterations were determined with both FISH and Q-PCR methods in 35 melanoma samples.

\section{Primer Design}

The primers were designed for the genes GNS, UBE2E1, FGF3, FGF4, FGF19, EMS1 and TAOS1 using Primer Express 2.0.0 software (Applied Biosystems, Foster City, USA) and Primer3 (Whitehead Institute, Cambridge, USA; http://biotools.idtdna. com/primerquest/; Table 2). To avoid the secondary structures, we used the web-based MFOLD version 3.2 software (http://www.bioinfo.rpi.edu/applications/ mfold//). ${ }^{31}$ The sequences of the primers for the CCND1 gene were downloaded from the RTPrimerDB database (http://medgen.ugent.be/rtprimerdb/). ${ }^{32}$ Primers were purchased from Biocenter Kft. (Szeged, Hungary).

\section{Real-Time Quantitative PCR Analysis}

Quantification of gene copy number was performed on 68 primary melanoma tissues and 6 melanoma 
Table 2 Sequences of oligonucleotides used for this study

\begin{tabular}{|c|c|c|}
\hline Gene & Forward primer $\left(5^{\prime} \rightarrow 3^{\prime}\right)$ & Forward primer $\left(5^{\prime} \rightarrow 3^{\prime}\right)$ \\
\hline GNS & TCCAACTTTGAGCCCTTCTT & CGTTCCATGGATGTTGAAGT \\
\hline UBE2E1 & GGTGGGAAGTATTGCCACTCA & GTGAAACCCCAATTTATGTAGCGTAT \\
\hline CCND1 & GCTCCTGGTGAACAAGCTCAA & TTGGAGAGGAAGTGTTCAATGAAA \\
\hline TAOS1 & TGCACGCACCTGTTTAAATTTTC & TTGGAGAGGAAGTGTTCAATGAAA \\
\hline FGF3 & GGGAACGCGAGTCCCTTTA & CCTTTTGTTGGCGAACCGT \\
\hline FGF19 & CGGATCTCCTCCTCGAAAGC & CCACTGTGGATTGCTCAGAGC \\
\hline FGF4 & CAACGCCTACGAGTCCTACA & AGGAAGTGGGTGACCTTCAT \\
\hline EMS1 & CAAGCTGAGGGAGAATGTCTT & TTGTTCCACACCAAATTTCC \\
\hline$B R A F \mathrm{~V} 600$ & CTCTTCATAATGCTTGCTCTGATAGG & TAGTAACTCAGCAG-CATCTCAGG \\
\hline NRAS Q61 & CACCCCCAGGATTCTTACAGA & GATGGCAAATACACAGAGGAAGC \\
\hline Fluorescence probes & Sensor $\left(5^{\prime} \rightarrow\right.$ Fluoroscein- $\left.3^{\prime}\right)$ & Anchor $\left(5^{\prime}\right.$-LCRed640 $\rightarrow$ Phosphate-3') \\
\hline$B R A F \mathrm{~V} 600$ & AGCTACAGTGAAATCTCGATGGAG & GGTCCCATCAGTTTGAACAGTTGTCTGGA \\
\hline NRAS Q61 & ATACAGCTGGACAAGAAGAG & AGTGCCATGAGAGACCAATACATGAGGA \\
\hline
\end{tabular}

Underlined sequences correspond to BRAF codon 600 and NRAS codon 61, respectively.

metastases using Q-PCR. We aimed to quantify the relative amounts of the target genes, all located in the 11q13 amplicon core, using two reference genes for normalization, GNS (12q14.3) and UBE2E1 (3p24.2). These reference genes have not yet been reported as having genetic abnormalities in melanomas analyzed by array CGH. To screen the copy number changes, two reference genes are needed to produce a robust, reliable and accurate quantification. ${ }^{33-36}$ Reactions were carried out using an ABI Prism 7000 sequence detector (Applied Biosystems).

The amplification mixtures $(25 \mu \mathrm{l})$ contained $1 \mu \mathrm{l}$ template DNA $(\sim 10 \mathrm{ng} / \mu \mathrm{l}), 12.5 \mu \mathrm{l}$ Power SYBRGreen PCR Master Mix (Applied Biosystems) and $100 \mathrm{nM}$ of each primer for TAOS1, FGF3, FGF19, UBE2E1 and FGF4, $200 \mathrm{nM}$ of the primer for CCND1 and $300 \mathrm{nM}$ of the primers for EMS1 and GNS. The reactions were performed under the following conditions: $10 \mathrm{~min}$ of polymerase activation at $95^{\circ} \mathrm{C}$ then 40 cycles at $95^{\circ} \mathrm{C}$ for $15 \mathrm{~s}$ and $60^{\circ} \mathrm{C}$ for $1 \mathrm{~min}$. Assay for each gene included: (1) no template control (in duplicate), (2) $10 \mathrm{ng}$ of calibrator DNA (Applied Biosystems; in triplicate) and (3) approximately $10 \mathrm{ng}$ of tumor DNA (in triplicate). A melting curve analysis was run after the amplification was completed and consisted of a $20 \mathrm{~min}$ slow ramp from 60 to $92^{\circ} \mathrm{C}$ using an ABI PRISM 7000 Sequence Detection System (Applied Biosystems). The derivative melting curves showed single melting peaks, which confirmed the high Q-PCR specificity (absence of primer dimers and other nonspecific products).

\section{Quantification and Data Analysis}

Quantification was performed using the Pfaffl method. ${ }^{37}$ This requires the efficiency to be known, which is determined from standard curves. To evaluate more accurately the PCR reaction efficiency, five-point standard curves from three different fourfold dilutions (ranging from 80.0 to $0.3 \mathrm{ng}$; in triplicate) were set up using melanoma cell line DNA (M24) for the different target genes and control DNA for the reference genes. To calculate the PCR amplification efficiency $\left(E=10^{-1 / \text { slope }}-1\right)$ we calculated the slope value from the three separated standard curves for the target genes and reference genes as well. Only standard curves $R^{2}$ value $>0.99$ were accepted (Table 3). Instead of interpolating unknown samples from a standard curve, we calculated the relative copy number (Ratio) solely based on the observed $C_{\mathrm{T}}$ values (equation (1))

Ratio $=$

$$
\frac{\left(1+E_{\text {target gene }}\right)^{-\Delta C_{\text {Ttarget gene }}}}{\sqrt{\left(1+E_{\text {reference gene1 } 1}\right)^{-\Delta C_{\text {Treference gene1 }}} \times\left(1+E_{\text {reference gene } 2}\right)^{-\Delta C_{\text {Treference gene2 }}}}}
$$

$E_{\text {target gene }}$ is the efficiency of the PCR reaction for the target gene, $E_{\text {reference gene }}$ is the efficiency of the PCR reaction for the reference gene, $\Delta C_{\mathrm{T}}$ target gene is the difference in threshold cycle value between the test sample and calibrator sample for the target gene, $\Delta C_{\mathrm{T} \text { reference gene }}$ is the difference in threshold cycle value between test sample and calibrator sample for reference gene.

The equation was applied to calculate the standard error (s.e.) of the relative copy number of the normalized target gene, as described Hoebeeck et $a l^{35}$ To determine whether the copy numbers of the investigated genes were significantly different from those of the controls, we determined a tolerance interval (TI) for the relative gene copy number, using the mean standard deviation (s.d.) of the $\Delta C_{\mathrm{T}}$ values for the target and reference genes in 12 healthy individuals according to the equation $\mathrm{TI}=2 \pm 2 \times$ s.d. $\Delta C_{\mathrm{T}}$, as described elsewhere. ${ }^{38}$ The TI range was $1.28-2.72$ for $C C N D 1,1.42-2.58$ for 
Table 3 The calculated PCR amplification efficiencies

\begin{tabular}{lccc}
\hline Gene & $\mathrm{R}^{2}$ value & $\begin{array}{c}\text { Linear regression } \\
\text { equation }\end{array}$ & $\begin{array}{c}\text { 95\% confidence } \\
\text { intervals, slope } \\
\left.\text { (E }=10^{-1 / s l o p e}-1\right)\end{array}$ \\
\hline GNS & 0.9977 & $Y=-3.38 \times X+27.08$ & -3.51 to -3.25 \\
UBE2E1 & 0.9974 & $Y=-3.47 \times X+30.10$ & -3.61 to -3.33 \\
CEND1 & 0.9960 & $Y=-3.52 \times X+27.94$ & -3.79 to -3.25 \\
TAOS1 & 0.9970 & $Y=-3.49 \times X+28.74$ & -3.95 to -3.64 \\
FGF3 & 0.9966 & $Y=-3.92 \times X+28.90$ & -3.65 to -3.32 \\
FGF19 & 0.9977 & $Y=-3.69 \times X+28.56$ & -4.08 to -3.77 \\
FGF4 & 0.9978 & $Y=-3.99 \times X+28.34$ & -3.83 to -3.55 \\
EMS1 & 0.9971 & 0.94 & -4.39 to -3.60 \\
\hline
\end{tabular}

TAOS1, 1.18-2.82 for FGF3, 1.10-2.90 for FGF4, 1.13-2.87 for FGF19 and 1.04-2.96 for EMS1. If the calculated copy number \pm s.e. exceeded the calculated upper limit, the gene(s) in the tumors were considered to be amplified.

\section{Detection of BRAF and NRAS Mutations}

Analysis of mutations in the $B R A F$ codon 600 and in the NRAS codon 61 was performed on LightCycler real time PCR System (Roche Diagnostics, GmbH, Mannheim, Germany) by melting curve analysis using fluorescent probes. All primers and probes were purchased from TIB Molbiol (Berlin, Germany; Table 2). Amplification was performed in glass capillaries using $50 \mathrm{ng}$ of sample DNA in a $10 \mu \mathrm{l}$ volume containing $1 \mu \mathrm{l} 10 \times$ LightCycler FastStart DNA Master HybProbe (Roche Diagnostics), $0.8 \mu \mathrm{l}$ $25 \mathrm{mM} \mathrm{MgCl}_{2}, 0.75 \mu \mathrm{l}$ DMSO, $1 \mu \mathrm{l}(5 \mu \mathrm{M})$ forward and reverse primer and $1 \mu \mathrm{l}(2 \mu \mathrm{M})$ of the anchor and sensor hybridization probe.

The reaction was performed under the following condition: initial denaturation at $95^{\circ} \mathrm{C}$ for $10 \mathrm{~min}$ and 45 cycles of amplification consisting of denaturation at $95^{\circ} \mathrm{C}$ for $0 \mathrm{~s}$, annealing at $52^{\circ} \mathrm{C}$ for $10 \mathrm{~s}$ and amplification at $72^{\circ} \mathrm{C}$ for $20 \mathrm{~s}$. Melting curve analysis was done as follows: PCR products were denatured for $1 \mathrm{~min}$ at $95^{\circ} \mathrm{C}$ then cooled down to $40^{\circ} \mathrm{C}$ for $1 \mathrm{~min}$ and warmed up to $72^{\circ} \mathrm{C}$ (ramping at $0.1^{\circ} \mathrm{C} / \mathrm{s}$ ) with continuous fluorescence detection before by a final cooling step at $40^{\circ} \mathrm{C}$ for $30 \mathrm{~s}$. The accuracy of the method was confirmed by direct sequencing (BIOMI Kft., Gödöllö, Hungary) of PCR products that showed deviation from the wild-type (WT) genomic DNA melting peak (Figure 1).

\section{Statistical Analysis}

Statistical tests were performed using STATA version 9.0 (StataCorp LP, TX, USA). Categorical variables were compared by Fisher's exact test and continuous variables by the Mann-Whitney $U$-test. Correlations between the results of Q-PCR and FISH analysis were defined by calculating the Spearman's rank correlation $\left(r_{\mathrm{s}}\right)$. Results were considered significant if $P<0.05$.

\section{Results}

\section{Tumor Samples}

A total of 74 fresh or frozen tissue samples were obtained from 70 patients ( 34 men and 36 women), of which 68 were primary melanomas and 6 were melanoma metastases, including 4 primary tumormetastasis pairs. The number of patients with at least 3 years of follow-up was 57. If the follow-up period was less than 3 years, clinical data for metastasis formation were not included in Table 1, which summarizes the clinicopathological data.

\section{Confirmation of Reference Genes Suitable for Normalization}

To check the validity of the genes used as reference genes (GNS/UBE2E1), we determined the copy number ratio of the genes in 14 normal control DNA samples and 74 tumor samples. The ratio for normal and tumor DNA were 0.92 (s.d.=0.072) and 0.96 (s.d. $=0.205$ ), respectively. The copy number ratios of the two reference genes in the normal and tumor DNA were similar $(P=0.7236$, Mann-Whitney test).

\section{Q-PCR Intra- and Interassay Variability}

To determine the intra- and interassay variability of the Q-PCR assay, the mean coefficient of variance (CV) and mean standard deviation (s.d.) were determined for each gene, calculated from samples run in triplicate using the transformation of $C_{\mathrm{T}}$ to the linear $2^{-C_{\mathrm{T}}}$ value. Overall, the intraassay variability was $8 \%$ (s.d. $=0.11$ ) and the interassay variability was $25 \%$ (s.d. =0.38; Table 4). Samples were retested if the CV was higher than $20 \%$.

\section{CCND1 Amplification in Melanoma Samples Detected by Q-PCR}

A total of 68 primary and 6 metastatic lesions were tested to identify CCND1 amplification by Q-PCR relative to the two reference genes (GNS and UBE2E1). Using this technique, we found CCDN1 amplification in 22 primary melanomas $(32 \%)$ and 1 metastasis 

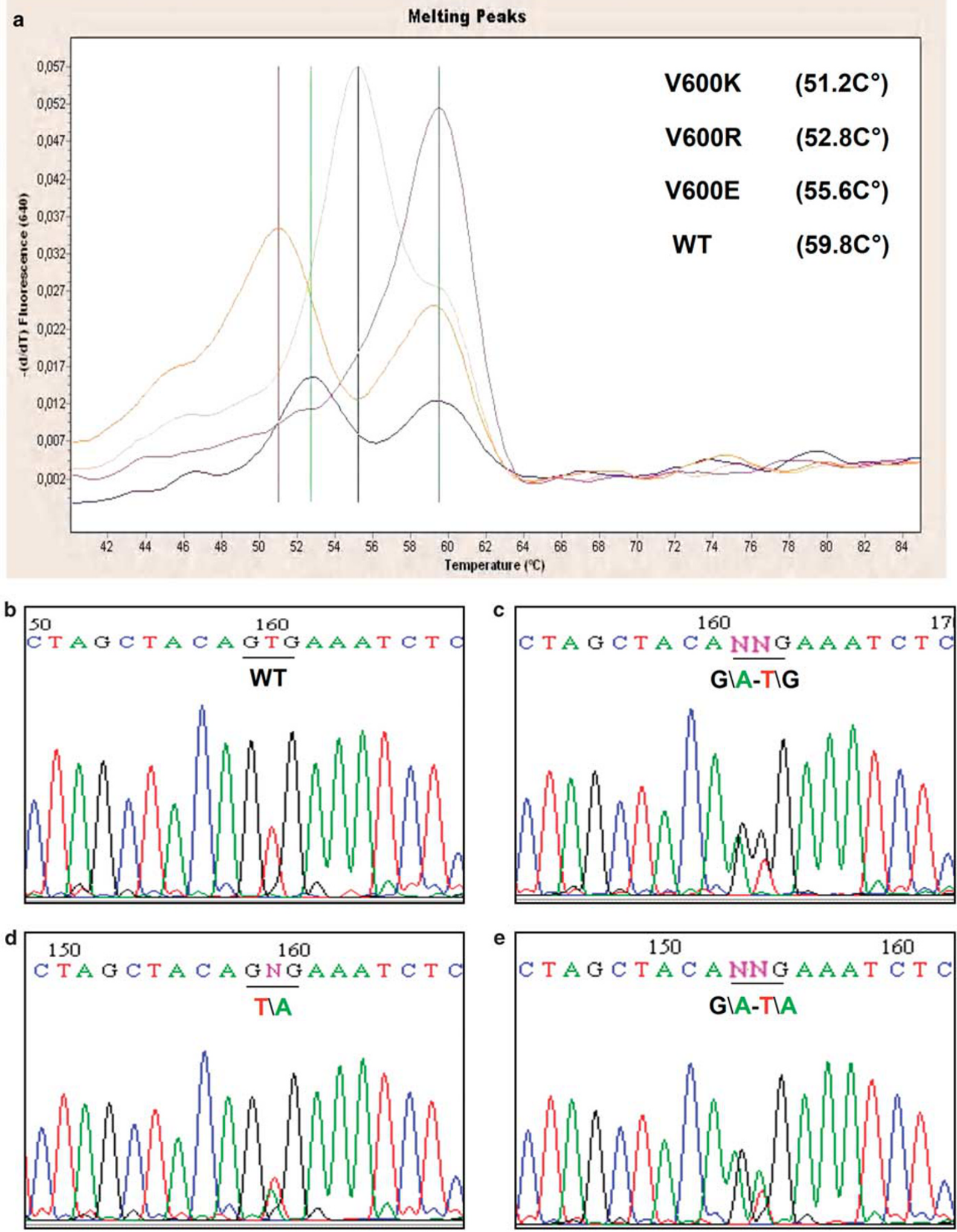

Figure 1 LightCycler melting curves and sequence traces of different BRAF types. (a) Typical results of melting curve analysis, (b) BRAF WT sequence (codon 600 is underlined) (c) V600R mutation (GT1798-99AG double base pair substitution), (d) V600E mutation (T1799A base pair substitution), (e) V600K mutation (GT1798-99AA double base pair substitution).

(Table 1). We were able to compare the CCND1 gene amplification pattern in the primary and its metastatic tumor in four cases: the CCND1 gene was amplified in all the primary lesions (case numbers 5, 22, 8 and 13; Table 5) but we could detect CCND1 amplification only one metastasis (data not shown). 
Table 4 Coefficient of variance (CV) and standard deviation (s.d.) for triplicate readings for intra- and interassay variability using $2^{-C_{\mathrm{T}}}$ values

\begin{tabular}{|c|c|c|c|c|c|c|}
\hline \multirow[b]{3}{*}{ Genes } & \multicolumn{3}{|c|}{ A: Intraassay variability } & \multicolumn{3}{|c|}{ B: Interassay variability } \\
\hline & \multicolumn{2}{|c|}{$\begin{array}{l}\text { Mean s.d. and CV from } \\
\text { triplicate readings, in the } \\
\text { same run }\end{array}$} & \multirow[b]{2}{*}{$\begin{array}{c}\text { Samples measured in } \\
\text { triplicate }\end{array}$} & \multicolumn{2}{|c|}{$\begin{array}{l}\text { Mean s.d. and CV from } \\
\text { triplicate readings, across } \\
\text { separate PCR runs }\end{array}$} & \multirow[b]{2}{*}{$\begin{array}{l}\text { Samples measured in } \\
\text { triplicate over } 2 \text { runs }\end{array}$} \\
\hline & $\begin{array}{l}\text { Mean } \\
\text { s.d. }\end{array}$ & $\begin{array}{c}\text { Mean } C V \\
(\%)\end{array}$ & & $\begin{array}{l}\text { Mean } \\
\text { s.d. }\end{array}$ & $\begin{array}{c}\text { Mean } C V \\
(\%)\end{array}$ & \\
\hline GNS & 0.13 & 9 & 79 & 0.47 & 30 & 7 \\
\hline$U B E 2 E 1$ & 0.11 & 8 & 81 & 0.46 & 30 & 6 \\
\hline$C C N D 1$ & 0.12 & 8 & 73 & 0.21 & 15 & 6 \\
\hline TAOS1 & 0.08 & 6 & 25 & 0.56 & 36 & 3 \\
\hline FGF3 & 0.09 & 5 & 27 & 0.33 & 23 & 5 \\
\hline FGF19 & 0.13 & 9 & 23 & 0.4 & 27 & 3 \\
\hline FGF4 & 0.14 & 10 & 26 & 0.18 & 12 & 4 \\
\hline \multirow[t]{3}{*}{ EMS1 } & 0.11 & 8 & 29 & 0.4 & 27 & 4 \\
\hline & $\begin{array}{l}\text { Overall } \\
\text { s.d. }\end{array}$ & $\begin{array}{c}\text { Overall } C V \\
(\%)\end{array}$ & Total & $\begin{array}{l}\text { Overall } \\
\text { s.d. }\end{array}$ & $\begin{array}{c}\text { Overall } C V \\
(\%)\end{array}$ & Total \\
\hline & 0.11 & 8 & 363 & 0.38 & 25 & 38 \\
\hline
\end{tabular}

Table 5 Coamplification of TAOS1, FGF3, FGF19, FGF4 and EMS1 with CCND1 detected by Q-PCR and BRAF V600, NRAS Q61 mutations in primary melanomas

Copy number \pm s.e.

\begin{tabular}{|c|c|c|c|c|c|c|c|c|}
\hline Cases & CCND1 & TAOS1 & FGF3 & FGF19 & FGF4 & EMS1 & $\mathrm{BRAF}+V 600$ & NRAS+ Q61 \\
\hline 1 & $13.4 \pm 0.60$ & $10.0 \pm 0.71$ & $5.00 \pm 0.61$ & $7.4 \pm 0.65$ & $7.9 \pm 0.62$ & $5.8 \pm 0.48$ & V600E & WT \\
\hline 2 & $5.4 \pm 0.31$ & $3.7 \pm 0.31$ & $4.5 \pm 0.22$ & $5.1 \pm 0.32$ & $4.1 \pm 0.25$ & $4.4 \pm 0.34$ & WT & Q61R \\
\hline 3 & $4.9 \pm 0.31$ & $3.6 \pm 0.23$ & $3.7 \pm 0.26$ & $3.9 \pm 0.26$ & $3.3 \pm 0.31$ & $4.6 \pm 0.29$ & V600E & WT \\
\hline 4 & $4.4 \pm 0.34$ & $4.4 \pm 0.27$ & $3.3 \pm 0.38$ & $7.4 \pm 0.65$ & $3.7 \pm 0.26$ & $5.2 \pm 0.32$ & WT & WT \\
\hline 5 & $11.7 \pm 0.34$ & $7.0 \pm 0.44$ & $3.8 \pm 0.23$ & $4.9 \pm 0.36$ & $4.0 \pm 0.44$ & No Amp & WT & WT \\
\hline 6 & $5.2 \pm 0.72$ & $5.0 \pm 0.71$ & $4.5 \pm 0.28$ & $4.6 \pm 0.19$ & $4.2 \pm 0.31$ & No $A m p$ & WT & WT \\
\hline 7 & $3.2 \pm 0.10$ & $3.0 \pm 0.22$ & $3.3 \pm 0.13$ & $3.8 \pm 0.22$ & No Amp & $3.8 \pm 0.13$ & WT & WT \\
\hline 8 & $3.7 \pm 0.19$ & $2.8 \pm 0.16$ & $3.3 \pm 0.26$ & No Amp & No Amp & No Amp & V600E & WT \\
\hline 9 & $4.2 \pm 0.28$ & $2.8 \pm 0.12$ & No Amp & No Amp & No Amp & $3.8 \pm 0.13$ & V600E & WT \\
\hline 10 & $3.5 \pm 0.48$ & $3.2 \pm 0.15$ & No Amp & No Amp & No Amp & $3.0 \pm 0.06$ & WT & WT \\
\hline 11 & $9.6 \pm 0.74$ & No Amp & No Amp & No Amp & No Amp & No Amp & WT & WT \\
\hline 12 & $4.6 \pm 0.10$ & No Amp & No Amp & No Amp & No Amp & No Amp & WT & WT \\
\hline 13 & $3.8 \pm 0.24$ & No Amp & No Amp & No Amp & No Amp & No Amp & WT & Q61K \\
\hline 14 & $3.5 \pm 0.15$ & No Amp & No Amp & No Amp & No Amp & No Amp & WT & Q61K \\
\hline 15 & $3.4 \pm 0.22$ & No Amp & No Amp & No Amp & No Amp & No Amp & WT & WT \\
\hline 16 & $3.1 \pm 0.30$ & No Amp & No Amp & No Amp & No Amp & No Amp & WT & Q61K \\
\hline 17 & $3.1 \pm 0.12$ & No Amp & No Amp & No Amp & No Amp & No Amp & WT & Q61K \\
\hline 18 & $3.1 \pm 0.14$ & No Amp & No Amp & No Amp & No Amp & No Amp & WT & Q61K \\
\hline 19 & $3.0 \pm 0.19$ & No Amp & No Amp & No Amp & No Amp & No Amp & V600E & WT \\
\hline 20 & $3.0 \pm 0.16$ & No Amp & No Amp & No Amp & No Amp & No Amp & V600R & WT \\
\hline 21 & $2.9 \pm 0.09$ & No Amp & No Amp & No Amp & No Amp & No Amp & WT & WT \\
\hline 22 & $2.9 \pm 0.12$ & No Amp & No Amp & No Amp & No Amp & No Amp & WT & Q61K \\
\hline
\end{tabular}

No Amp, amplification was not detected; WT, wild type BRAF or NRAS genotype.

\section{Comparing Gene Copy Number for CCND1: Q-PCR versus FISH}

When we compared the CCND1 gene copy number alterations obtained by Q-PCR with those detected by FISH, we found a good agreement between the two methods (Figure 2). The average CCND1 copy number varied from 1.9 to 15.0 by FISH and from 1.8 to 13.4 by Q-PCR. We were able to detect amplification by Q-PCR in 8 out of 10 cases in which the frequency of amplified cells was more than $30 \%$ (copy number $\geq 5 /$ cell) and in all cases in which the gene/centromere ratio was above 2 (Table 6). We did not observe amplification by Q-PCR if the disomic 
cell population was above $>50 \%$ (data not shown). The Spearman's rank correlation coefficient showed strong correlations between FISH and Q-PCR results $(r=0.6, P<0.001)$. In sample 7 , a high-level amplification was seen by FISH, but the average copy number of the CCND1 gene was only 3.2 by Q-PCR. The reason for this discrepancy may be that the touch preparation and the DNA were from slightly different parts of the tumor or a high copy number heterogeneity existed within the sample.

\section{Evaluation of TAOS1, FGF3, FGF4, FGF19 and EMS1 Gene Copy Numbers by Q-PCR}

Samples with CCND1 amplification (22 primary melanomas) were further characterized for the TAOS1, FGF3, FGF4, FGF19 and EMS1 gene copy number alterations by Q-PCR. Among these 22 samples, $18 \%$ (4/22) showed amplification for all of these additional five genes (Table 5). In $46 \%$ of tumors (10/22) CCND1 was coamplified with TAOS1; 36\% (8/22) of CCND1-amplified tumors also displayed amplification of FGF3. Coamplification of CCND1 and EMS1 was observed in 7 lesions (32\%). The nine primary melanoma samples which exhibited higher CCND1 gene copy numbers (range 4.213.4) tended to display TAOS1 (7/9), FGF3 (6/9), FGF19 (6/9), FGF4 (6/9) and EMS1 (5/9) amplifications as well (see details in Table 5).

\section{$B R A F$ and $N R A S$ Mutation Frequencies}

$B R A F$ mutations at codon 600 were found in 25 out of 68 primary melanomas $(37 \%)$ and in 2 out of 6 metastases. Eighteen (27\%) primary and two metastatic lesions had $B R A F$ exon 15, codon V600E mutations. This mutation is a single-base $\mathrm{T} \rightarrow \mathrm{A}$ transition (T1799A), resulting in a valine to glutamine change and causing substitution with a negatively charged residue. Seven primary tumors (10\%) with V600 mutations were double base pair tandem substitutions; five (7\%) had a V600K (GT1798-99AA) mutation, causing a valine to lysine change in the amino acid; two (3\%) had a V600R tandem mutation
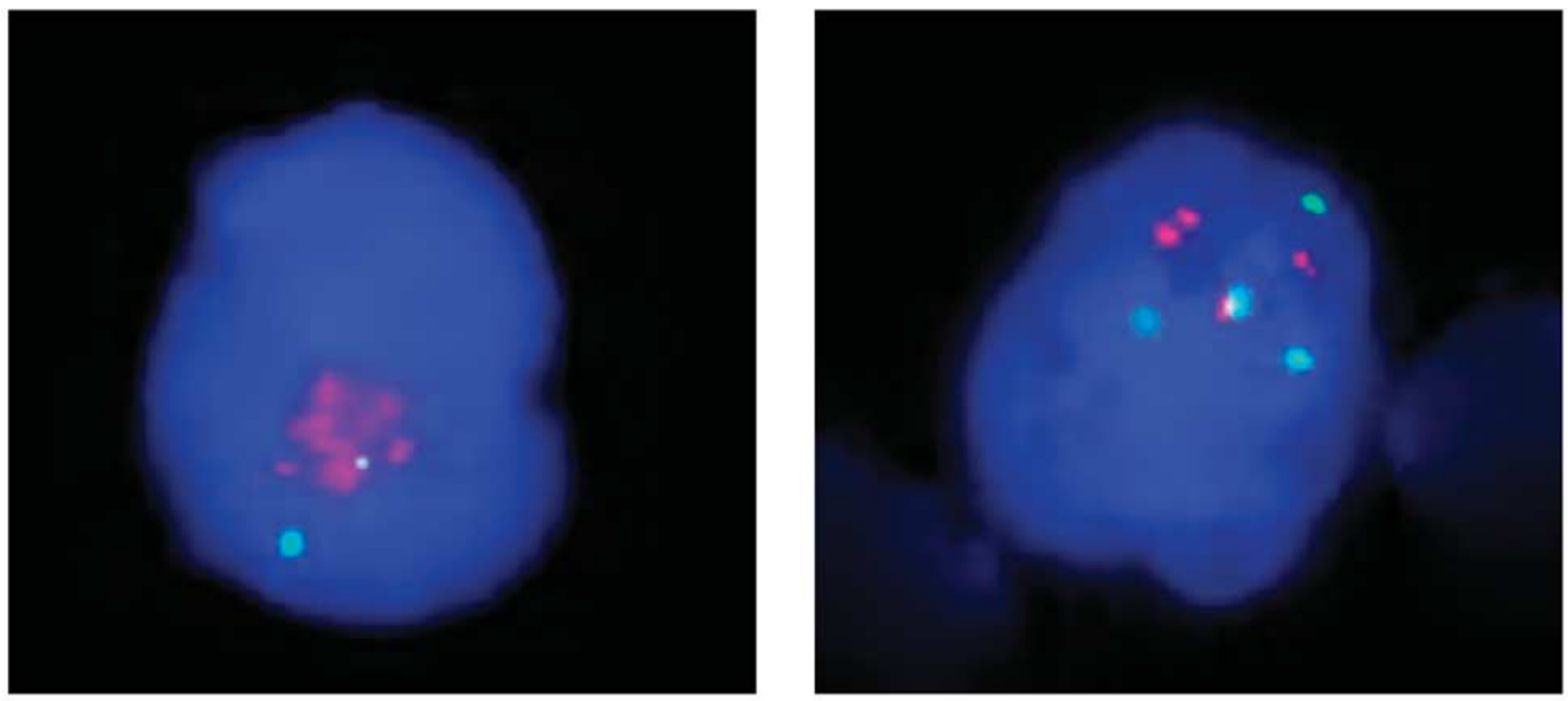

Signals/cell by FISH (\%)

\begin{tabular}{llccc}
\hline Tumor sample & 2 & $3-4$ & $\begin{array}{c}\text { Gene /centromere } \\
\text { ratio }\end{array}$ \\
\hline
\end{tabular}

(a) tumor \# 1

0

0

100

7.5

1.0

(b) tumor \# 42

79

17

0
Average gene copy number

FISH

Q-PCR

2.2

Figure 2 Comparison of copy number alterations of the CCND1 gene detected by FISH and Q-PCR analysis. CCND1 gene specific probe was labeled with Spectrum Orange (appearing as red signals) and chromosome 11 centromeric probe was labeled with Spectrum Green (appearing as green signals), cell nuclei were labeled with blue fluorescent dye (DAPI). (a) Image represents a high-level amplification for the CCND1 gene whereas (b) image shows tetrasomy for both centromeric and gene regions. 
Table 6 Comparison of copy number alterations of the CCND1 gene obtained by FISH and Q-PCR analysis

\begin{tabular}{|c|c|c|c|c|c|c|}
\hline \multirow[b]{2}{*}{ Tumor sample } & \multicolumn{3}{|c|}{ Signals/cell by FISH (\%) } & \multirow[b]{2}{*}{ Ratio (gene/centromere) } & \multicolumn{2}{|c|}{ Average copy number } \\
\hline & 2 & $3-4$ & $\geq 5$ & & FISH & $Q-P C R$ \\
\hline 1 & 0 & 0 & 100 & 7.5 & 15.0 & 13.4 \\
\hline 7 & 0 & 0 & 100 & 6.9 & 15.0 & 3.2 \\
\hline 5 & 5 & 39 & 56 & 2.4 & 9.1 & 11.7 \\
\hline 2 & 8 & 36 & 56 & 3.4 & 8.7 & 5.4 \\
\hline 11 & 28 & 39 & 33 & 2.3 & 5.9 & 9.6 \\
\hline 3 & 18 & 49 & 31 & 1.5 & 5.3 & 4.9 \\
\hline 6 & 13 & 30 & 54 & 2.4 & 5.0 & 5.2 \\
\hline 10 & 8 & 49 & 43 & 1.2 & 5.0 & 3.5 \\
\hline 24 & 8 & 46 & 47 & 1.6 & 6.8 & No amp \\
\hline 25 & 31 & 35 & 32 & 0.8 & 4.1 & No amp \\
\hline
\end{tabular}

No Amp, amplification was not detected.

(GT1798-99AG), causing a valine to arginine change, both of which mutations resulted in a substitution of valine for a positively charged amino acid (Figure 1).

NRAS mutations at codon 61 were found in 13 out of 68 primary melanomas $(19 \%)$ and in 2 out of 6 metastases. The two most frequently observed mutations were a CAA to AAA transversion, which occurred in seven primary lesions $(10 \%)$ and two metastases (resulting in a Q61K change) and a CAA to CGA transition, which occurred in five primary tumors (7\%; resulting in a Q61R change). A CAA to TTA tandem mutation was observed in one lesion ( $2 \%$; resulting in a Q61L change). Furthermore, $56 \%$ of primary melanomas and 3 metastases had either $B R A F$ or NRAS mutations, but both mutations were never simultaneously present. CCND1 was amplified in $34 \%$ of $B R A F$ or NRAS mutated primary melanoma samples (Table 5).

In four patients, both primary and metastatic tumors were analyzed. Mutations in the primary tumors (one carrying a V600E mutation, two harboring a Q61K mutation) also occurred in the corresponding metastatic lesions (data not shown).

\section{Correlation of Gene Alterations with Clinicopathological Parameters}

We did not find correlations between CCND1 gene amplification status and any of the patients' clinicopathological parameters.

Tumors with CCND1 and TAOS1 coamplification were classified with higher Clark's level (IV-V). Ulcerated tumors had a statistically significant association with CCND1 and TAOS1 coamplification $(P=0.017$; Table 1$)$. In addition, coamplification of CCND1 with TAOS1 $(P<0.001), F G F 3$ $(P=0.001), F G F 19(P<0.001), F G F 4(P=0.002)$ and EMS1 $(P=0.004)$ genes, respectively, were more frequently found in thick ( $\geq 9 \mathrm{~mm}$ Breslow thickness) melanomas. Younger age at diagnosis was significantly associated with coamplification of these five oncogenes (CCND1, TAOS1, FGF3,
FGF19 and FGF4; $P=0.026$, Mann-Whitney test; data not shown).

NRAS codon 61 mutations were significantly more frequent in tumors originating from chronically sun-exposed sites $(P=0.005$; Table 1$)$. Other clinical parameters did not show significant association with the prevalence of BRAF or NRAS mutations. However, an increased CCND1 gene copy number in conjunction with either BRAF or NRAS activation mutations was significantly more common in primary tumors with ulcerated surfaces $(P=0.028$; data not shown $)$.

\section{Discussion}

We have elaborated a relative Q-PCR assay to assess the copy number profile of candidate genes located within the 11q13 chromosomal segment in primary malignant melanomas. This Q-PCR assay resulted in accurate measurement of DNA copy number alterations and can be used as an independent, sensitive method in parallel with other techniques such as Southern blot and FISH. The advantages of the technique are low cost and a requirement for only a very small amount of DNA, meaning that early-stage lesions of small size can be also analyzed. In addition, this PCR assay can be designed and validated for any loci with a known sequence in the human genome within a short period of time.

We had to consider a number of important parameters during the design of the Q-PCR assays for the quantification of the target genes within the $11 q 13$ amplicon core. For normalization and to increase the reliability of the assay, we chose two reference genes (GNS on 12q14.3 and UBE2E1 on $3 p 24.2$ ), which are not thought to have copy number alterations in melanoma. The validity and reliability of both genes as reference genes were revealed through the detection of the copy number ratio in normal DNA and melanoma tumor samples as described earlier by De Preter et al. ${ }^{33}$ The gene copy number ratio of the tumor samples is frequently calculated using the method described by Pfaffl 
et $a .^{37}$ When using this method, the relative gene copy number ratio is calculated only from the QPCR efficiencies and the crossing-point deviation of an unknown sample versus a control sample; it needs no calibration curve, as control levels are included in the model. However, to evaluate the reproducibility of the Q-PCR assays we calculated the coefficient of variation (CV) using the transformation of $C_{\mathrm{T}}$ to the linear $2^{-C_{\mathrm{T}}}$ value (calculating $\mathrm{CV}$ based on raw $C_{\mathrm{T}}$ values produces incorrect results because of its logarithmic nature ${ }^{39}$ ). Using our approach, the overall intra- and interassay variability of the experiments was 8 and $25 \%$, respectively. These values are in good agreement with those reported by others. ${ }^{40-42}$ The calculated low CVs were critical for the reliability of the designed Q-PCR assay and were the result of the accurate PCR reaction setup and the high quality of the DNA templates used during the entire experiment.

We were able to compare FISH and Q-PCR data for the CCND1 gene in case of 35 primary melanomas and found good concordance. Q-PCR was sensitive enough to detect gene amplification if the copy number was $\geq 5$ in more than $30 \%$ of tumor cells. The rare discrepancies between Q-PCR and FISH were probably resulted from higher normal cell contamination or could be explained by genetically heterogeneous tumor cell clones in the analyzed samples. ${ }^{33}$

In addition, we evaluated the CCND1 gene copy number in all melanoma samples. Thirty-two percent of the primary lesions exhibited amplification. In contrast to a previous study, ${ }^{16}$ but in confirmation of a recently published data, ${ }^{17}$ we found that $C C N D 1$ amplification was similarly frequent in SSM and NM. We did not observe any associations between CCND1 gene alterations and clinicopathological parameters. Comparing the CCND1 gene copy numbers in four primary and metastatic tumor pairs, we found gene amplification in all primary tumors but only one metastasis.

Recently it was found that CCND1 is coamplified with other genes located within the 11q13 region in several malignancies, and it is likely that these coamplifications play a pathogenic role in those cancers. ${ }^{12,13,22}$ However, no data are available for melanoma. To define the coamplification pattern of genes in the 11q13 amplicon, we designed Q-PCR assays for the TAOS1, FGF3, FGF19, FGF4 and EMS1 genes. The coamplification of CCND1 with TAOS1 was the most frequent event and had a significant association with the presence of ulceration $(P=0.017)$, a clinical feature that can predict poor prognosis. TAOS1 has been described as a possibly important gene that might drive the $11 \mathrm{q} 13$ amplification in oral squamous cell carcinoma and associated with poor prognosis. ${ }^{10,13}$ RNA interference method predicts that TAOS1 would participate in cell-cycle control and regulate cell proliferation, similarly to CCND1. ${ }^{10}$ We have shown that coamplifications of each of these genes with CCND1 are characteristic for thick melanomas and are present in patients of younger age. Based on our data we assume that coamplification of these candidate genes can contribute to a more aggressive phenotype than CCND1 amplification alone. It is also possible that the coamplifications are merely a result of genetic instability that increases during tumor progression but do not contribute directly to the phenotypic alterations. ${ }^{43}$

The BRAF V600E mutation frequency in our samples was $26 \%$, which is in concordance with other studies ${ }^{44,45}$ but the occurrence of this mutation was lower than it has been reported elsewhere. ${ }^{4,46}$ We detected two other BRAF mutations that were distinct from the V600E mutation. In each case, subsequent sequencing revealed the presence of V600K or V600R tandem mutations with rates of 7 and $3 \%$, respectively. The two most frequently observed NRAS mutations were Q61K and Q61R, with rates of 10 and $7 \%$, respectively, and these were associated exclusively with tumors derived from chronically sun-exposed sites, which agrees with past studies. ${ }^{46,47}$ Metastatic lesions harbored the same mutations as the primary tumor from which they originated, which supports the idea that these mutations are preserved throughout melanoma progression. ${ }^{48}$

A recent study analyzing 126 melanomas found that lesions with increased CCND1 expression level had either mutation in BRAF or NRAS or increased copy number of the CCND1 gene, without exception. The study reported a strong inverse correlation between BRAF mutations and increased CCND1 copies. This suggests that an increased level of CCND1 protein (the downstream component of the $R A S / B R A F / M A P$ kinase pathway), as a result of either mutations in upstream genes or increased gene dosage, represents a crucial event driving melanoma progression. ${ }^{4}$ Evaluating the relationship between increased CCND1 gene dosage and the frequency of $B R A F$ and NRAS mutations, we found that $34 \%$ of the primary melanomas harboring one of these activating mutations also had CCND1 alterations. Among these tumors, melanomas with ulcerated surfaces were significantly more frequently present $(P=0.028)$, indicating the clinical relevance of this finding. This association is supported by a recent study in which CCND1 was found to be amplified and overexpressed in $17 \%$ of $B R A F$ V600E-mutated human metastatic melanomas and contributed to increased $B R A F$ inhibitor resistance in melanomas. ${ }^{49}$

In conclusion, Q-PCR is a fast, reliable and accurate method for detecting amplification present in the 11q13 amplicon core in malignant melanomas. We found that neither the increased CCND1 gene dosage nor the $B R A F$ or the NRAS mutations alone contributed to more aggressive phenotype. However, we assume that coamplification of these candidate genes in the $11 \mathrm{q} 13$ region or carrying a CCND1 alteration along with either the activating 
$B R A F$ or NRAS mutation may be more important for prognosis in subgroups of aggressive melanomas than the presence of these alterations alone.

\section{Disclosure/conflict of interest}

The research was supported by the Hungarian National Research Fund (grants OTKA T04875 and OTKA K75191), the National Research and Development Program, Hungary (grant NKFP1-00003/ 2005). The authors have no connection to any companies or products mentioned in this article.

\section{References}

1 Rodolfo M, Daniotti M, Vallacchi V. Genetic progression of metastatic melanoma. Cancer Lett 2004;214: 133-147.

2 Balazs M, Adam Z, Treszl A, et al. Chromosomal imbalances in primary and metastatic melanomas revealed by comparative genomic hybridization. Cytometry 2001;46:222-232.

3 Bastian BC, LeBoit PE, Hamm H, et al. Chromosomal gains and losses in primary cutaneous melanomas detected by comparative genomic hybridization. Cancer Res 1998;58:2170-2175.

4 Curtin JA, Fridlyand J, Kageshita T, et al. Distinct sets of genetic alterations in melanoma. $N$ Engl J Med 2005;353:2135-2147.

5 Yurakh AO, Ramos D, Calabuig-Farinas S, et al. Molecular and immunohistochemical analysis of the prognostic value of cell-cycle regulators in urothelial neoplasms of the bladder. Eur Urol 2006;50:506-515; discussion 15.

6 Akervall J, Borg A, Dictor M, et al. Chromosomal translocations involving 11q13 contribute to cyclin D1 overexpression in squamous cell carcinoma of the head and neck. Int J Oncol 2002;20:45-52.

7 Elsheikh S, Green AR, Aleskandarany MA, et al. CCND1 amplification and cyclin D1 expression in breast cancer and their relation with proteomic subgroups and patient outcome. Breast Cancer Res Treat 2008;109:325-335.

8 Rodrigo JP, Garcia LA, Ramos S, et al. EMS1 gene amplification correlates with poor prognosis in squamous cell carcinomas of the head and neck. Clin Cancer Res 2000;6:3177-3182.

9 Komatsu Y, Hibi K, Kodera Y, et al. TAOS1, a novel marker for advanced esophageal squamous cell carcinoma. Anticancer Res 2006;26:2029-2032.

10 Xia J, Chen Q, Li B, et al. Amplifications of TAOS1 and EMS1 genes in oral carcinogenesis: association with clinicopathological features. Oral Oncol 2007; 43:508-514.

11 Schuuring E. The involvement of the chromosome 11q13 region in human malignancies: cyclin D1 and EMS1 are two new candidate oncogenes-a review. Gene 1995;159:83-96.

12 Zaharieva BM, Simon R, Diener PA, et al. Highthroughput tissue microarray analysis of $11 \mathrm{q} 13$ gene amplification (CCND1, FGF3, FGF4, EMS1) in urinary bladder cancer. J Pathol 2003;201:603-608.

13 Huang X, Gollin SM, Raja S, et al. High-resolution mapping of the 11q13 amplicon and identification of a gene, TAOS1, that is amplified and overexpressed in oral cancer cells. Proc Natl Acad Sci USA 2002;99: 11369-11374.

14 Filmus J, Robles AI, Shi W, et al. Induction of cyclin D1 overexpression by activated ras. Oncogene 1994;9: 3627-3633.

15 Sherr CJ, Roberts JM. CDK inhibitors: positive and negative regulators of G1-phase progression. Genes Dev 1999;13:1501-1512.

16 Sauter ER, Yeo UC, von Stemm A, et al. Cyclin D1 is a candidate oncogene in cutaneous melanoma. Cancer Res 2002;62:3200-3206.

17 Utikal J, Udart M, Leiter U, et al. Additional Cyclin $\mathrm{D}(1)$ gene copies associated with chromosome 11 aberrations in cutaneous malignant melanoma. Int J Oncol 2005;26:597-605.

18 Patel AS, Schechter GL, Wasilenko WJ, et al. Overexpression of EMS1/cortactin in NIH3T3 fibroblasts causes increased cell motility and invasion in vitro. Oncogene 1998;16:3227-3232.

$19 \mathrm{Wu} \mathrm{H}$, Parsons JT. Cortactin, an 80/85-kilodalton pp60src substrate, is a filamentous actin-binding protein enriched in the cell cortex. J Cell Biol 1993;120:1417-1426.

20 Pasello G, Agata S, Bonaldi L, et al. DNA copy number alterations correlate with survival of esophageal adenocarcinoma patients. Mod Pathol 2009;22: $58-65$.

21 Timpson P, Wilson AS, Lehrbach GM, et al. Aberrant expression of cortactin in head and neck squamous cell carcinoma cells is associated with enhanced cell proliferation and resistance to the epidermal growth factor receptor inhibitor gefitinib. Cancer Res 2007;f67:9304-9314.

22 Bringuier PP, Tamimi Y, Schuuring E, et al. Expression of cyclin D1 and EMS1 in bladder tumours; relationship with chromosome 11q13 amplification. Oncogene 1996;12:1747-1753.

23 Davies H, Bignell GR, Cox C, et al. Mutations of the BRAF gene in human cancer. Nature 2002;417: 949-954.

24 Omholt K, Karsberg S, Platz A, et al. Screening of N-ras codon 61 mutations in paired primary and metastatic cutaneous melanomas: mutations occur early and persist throughout tumor progression. Clin Cancer Res 2002;8:3468-3474.

25 Sebolt-Leopold JS, Herrera R. Targeting the mitogenactivated protein kinase cascade to treat cancer. Nat Rev Cancer 2004;4:937-947.

26 Tsai J, Lee JT, Wang W, et al. Discovery of a selective inhibitor of oncogenic B-Raf kinase with potent antimelanoma activity. Proc Natl Acad Sci USA 2008;105:3041-3046.

27 King AJ, Patrick DR, Batorsky RS, et al. Demonstration of a genetic therapeutic index for tumors expressing oncogenic BRAF by the kinase inhibitor SB-590885. Cancer Res 2006;66:11100-11105.

28 Smalley KS, Flaherty KT. Integrating BRAF/MEK inhibitors into combination therapy for melanoma. Br J Cancer 2009;100:431-435.

29 Rousseau Jr DL, Gershenwald JE. The new staging system for cutaneous melanoma in the era of lymphatic mapping. Semin Oncol 2004;31:415-425.

30 Rakosy Z, Vizkeleti L, Ecsedi S, et al. EGFR gene copy number alterations in primary cutaneous malignant melanomas are associated with poor prognosis. Int J Cancer 2007;121:1729-1737. 
31 Zuker M. Mfold web server for nucleic acid folding and hybridization prediction. Nucleic Acids Res 2003;31:3406-3415.

32 Pattyn F, Speleman F, De Paepe A, et al. RTPrimerDB: the real-time PCR primer and probe database. Nucleic Acids Res 2003;31:122-123.

33 De Preter K, Speleman F, Combaret V, et al. Quantification of MYCN, DDX1, and NAG gene copy number in neuroblastoma using a real-time quantitative PCR assay. Mod Pathol 2002;15:159-166.

34 Pfaffl MW, Georgieva TM, Georgiev IP, et al. Real-time RT-PCR quantification of insulin-like growth factor (IGF)-1, IGF-1 receptor, IGF-2, IGF-2 receptor, insulin receptor, growth hormone receptor, IGF-binding proteins 1, 2 and 3 in the bovine species. Domest Anim Endocrinol 2002;22:91-102.

35 Hoebeeck J, Speleman F, Vandesompele J. Real-time quantitative PCR as an alternative to Southern blot or fluorescence in situ hybridization for detection of gene copy number changes. Methods Mol Biol 2007;353: 205-226.

36 Hoebeeck J, van der Luijt R, Poppe B, et al. Rapid detection of VHL exon deletions using real-time quantitative PCR. Lab Invest 2005;85:24-33.

37 Pfaffl MW. A new mathematical model for relative quantification in real-time RT-PCR. Nucleic Acids Res 2001;29:e45.

38 Kindich R, Florl AR, Jung V, et al. Application of a modified real-time PCR technique for relative gene copy number quantification to the determination of the relationship between NKX3.1 loss and MYC gain in prostate cancer. Clin Chem 2005;51:649-652.

39 Schmittgen TD, Zakrajsek BA, Mills AG, et al. Quantitative reverse transcription-polymerase chain reaction to study mRNA decay: comparison of endpoint and real-time methods. Anal Biochem 2000;285: 194-204.

40 Smith CJ, Nedwell DB, Dong LF, et al. Evaluation of quantitative polymerase chain reaction-based approaches for determining gene copy and gene transcript numbers in environmental samples. Environ Microbiol 2006;8:804-815.

41 Dionisi HM, Harms G, Layton AC, et al. Power analysis for real-time PCR quantification of genes in activated sludge and analysis of the variability introduced by DNA extraction. Appl Environ Microbiol 2003;69: 6597-6604.

42 Murphy RM, Watt KK, Cameron-Smith D, et al. Effects of creatine supplementation on housekeeping genes in human skeletal muscle using real-time RT-PCR. Physiol Genomics 2003;12:163-174.

43 Bastian BC. Understanding the progression of melanocytic neoplasia using genomic analysis: from fields to cancer. Oncogene 2003;22:3081-3086.

44 Hay R, MacRae E, Barber D, et al. BRAF mutations in melanocytic lesions and papillary thyroid carcinoma samples identified using melting curve analysis of polymerase chain reaction products. Arch Pathol Lab Med 2007;131:1361-1367.

45 Poynter JN, Elder JT, Fullen DR, et al. BRAF and NRAS mutations in melanoma and melanocytic nevi. Melanoma Res 2006;16:267-273.

46 Thomas NE, Edmiston SN, Alexander A, et al. Number of nevi and early-life ambient UV exposure are associated with BRAF-mutant melanoma. Cancer Epidemiol Biomarkers Prev 2007;16:991-997.

47 van Elsas A, Zerp SF, van der Flier S, et al. Relevance of ultraviolet-induced N-ras oncogene point mutations in development of primary human cutaneous melanoma. Am J Pathol 1996;149:883-893.

48 Omholt K, Platz A, Kanter L, et al. NRAS and BRAF mutations arise early during melanoma pathogenesis and are preserved throughout tumor progression. Clin Cancer Res 2003;9:6483-6488.

49 Smalley KS, Lioni M, Dalla Palma M, et al. Increased cyclin D1 expression can mediate BRAF inhibitor resistance in BRAF V600E-mutated melanomas. Mol Cancer Ther 2008;7:2876-2883. 